\title{
Evaluation of the Progress, Drawbacks and Plan of Change Army Activities of Students and Teachers in Bule Hora University College of Natural and Computational Science
}

\author{
Mr.Million Chimdessa $^{1^{*}} \quad$ Mr.Kinfe W/Giorgis $^{2} \quad$ Mr.Abdi Tesfaye $^{3} \quad$ Mr.Utura Bululta $^{4}$ \\ 1.College of Natural and Computational Science Department of Biology \\ 2. College of Natural and Computational Science Department of Physics \\ 3. College of Natural and Computational Science Department of Statistics \\ 4. College of Natural and Computational Science Department of Geology
}

\begin{abstract}
The study was conducted at Bule Hora University College of Natural and Computational Science on Evaluation of the Progress, Drawbacks and Plan of Change Army activities of Students and Teachers. Cooperative learning is one of the most commonly used forms of active learning method through an individual's interaction with their environment and peers. Cooperative learning is largely based on the idea that students can learn through social contexts. The main objective of this action research was to assess the current status of Change Army activities in 1 to 5 group work within Faculty of Natural and Computational Science in Blue Hora University. For the purpose of this reseatch stratified random simpling (SRS) were considered. From these all total students and teachers, samples were taken from $1^{\text {st }}$ year upto $4^{\text {th }}$ year of regular students (129) and all department teachers (39). Within NSC majority of teachers and students have basic information about the purpose and importance of 1 to 5 grouping. Based on teachers' evaluation, $43.6 \%$ of the respondent gave "Good" mark and $25.6 \%$ gave "poor". However, based on students" evaluation, $34.9 \%$ of the students gave "Good" mark and $22.5 \%$ "poor". This indicated that 1 to 5 group activities within NSC has been implemented below satisfaction. This indicated there were many problems in understanding of the purpose of Change Army. Hence, it will be better if there is a tangible clarification about the purpose of Change Army activity and quick response for every question as much as possible.
\end{abstract}

Keywords: Change Army, One to Five, Teacher, Students, Group, Cooperative learning

DOI: $10.7176 / \mathrm{JEP} / 11-22-02$

Publication date:August $31^{\text {st }} 2020$

\section{Introduction}

\subsection{Cooperative learning}

One of the greatest and inevitable challenges educators face is determining the most effective teaching strategies for their students. Understanding and assessing student involvement in learning can help teachers design the most effective curriculum and determine how students' best learn. In addition, instructors must consider which skills will be most practical for students entering a workforce where building relationships and productivity go hand-inhand. To meet the demand, many educators are using active learning pedagogies, such as cooperative or teambased learning (Menges and Weimer, 1996).

Active learning in the context of higher education is often a social and informal process where ideas are casually exchanged through student involvement and intellectual and interpersonal activities. Cooperative learning is one of the most commonly used forms of active pedagogy taking place through an individual's interaction with his or her environment and peers, cooperative learning is largely based on the idea that students learn through social contexts (Adams and Hamm, 1994). While cooperative learning has been found to be an effective pedagogical tool in a broad range of subjects, limited research explores this form of active pedagogy as it pertains to higher education, and specifically the communication field.

Cooperative learning become a commonly used form of active learning in 1880's and continues to be valuables tool for learning in academic institution today (Johnson and smith 2007 ), as it provides benefit for both students and instructors (shimozoe and Aldrich, 2010). Slavin (1996) described cooperative learning as teaching method in which students work together in small groups to help one another learn academic content.

Johnson and smith (1991) outlined several central elements comprising cooperative learning including positive interdependence, individual accountability, face to face promotive interaction, appropriate use of collaborative skills and group processing as will be discussed further studies on cooperative learning have indicated its positive relationship with student achievement and attitude about learning (Slavin, 1989; Johnson and smith, 2007).

\subsection{Research question and hypotheses}

Although a great deal of work has explored active learning pedagogy in a variety of disciplines, this study specifically explores the efficacy of cooperative learning in the communication field. 
Examining how cooperative learning relates to student performance in a college level communication course raised the research question: What is the relationship between student involvement in cooperative learning and academic performance in a communication research methods course?

\section{Objectives}

\subsection{General objective}

The main objective of this action research was to assess the current status of Change Army activities in 1 to 5 group work within College of Natural and Computational Science in Blue Hora University.

\subsection{Specific objectives}

$>$ To check the progress change in teaching learning process that comes from implementation of 1 to 5 group activities in both students and teachers

$>$ To identify drawbacks that hindered it from implementation

$>$ To observe whether the students and teachers have plan on 1 to 5 group activities to do in a better performance for the future

\section{Methodology}

\subsection{Description of the study area}

Bule Hora district is found in southern part of Ethiopia, west Guji zone of Oromia regional which is $467 \mathrm{~km}$ away from Addis Ababa. Bule Hora University is also found within Bule Hora district. This research was conducted herein Bule Hora University in FNCS for each department such as: Statistics, Biology, Physics, Chemistry, Geology and Mathematics.

\subsection{Data collection}

Primary data are directly collected by the researcher while secondary data can be gathered from already existing information which has previously been collected and reported by individual or organization for their own purpose. For the porpuse of this research primary data collection method was preferred. Based on this, data were collected using questionnarie from teachers and regular students of Bule Hora University of NSC. The questionnire was designed as closed and open types of questions by considering the idea of the respondents.

\subsection{Sampling design}

A sampling design is a joint effort of survey statistician and other experts such as subject matter specialists, data users, and survey executing agency. There are different kinds of sampling designs depending on the type of study being conducted. For the purpose of this reseatch stratified random simpling (SRS) were considered.

In stratified sampling the population was partitioned into groups called strata, and sampling was performed separately within each stratum. Stratum variables are mutually exclusive non-over lapping. Therefore, population (elements) should be homogenous within-stratum and heterogeneous between the strata.

\subsection{Sample size determination}

The factors which decide the scale of survey of operations is by cost, time, operational constriants and the desired precision of the results. One of the most common questions that is asked by survey methology is sample size determination. It is known that more reliable information is obtained from large sample size because it gives accurated and successful results on the finding. However, taking of larg sample size beyond the limitation is not advisable because of time and cost drawbacks. Therefore, taking of right and appropriate sample size is necessary. Based on this assumption, for the porpose of this research, a small number of respondents were taken in to consideration from both students and teachers. At the momet of this research the total number of regular students that are exist in NSC is 1087 while teachers that are present in their work is 75 . From these all total students and teachers, samples were taken from $1^{\text {st }}$ year upto $4^{\text {th }}$ year of regular students (129) and all department teachers (39). This sample number is in agreement with the following calculation of sample size determination.

where $n o=\frac{(Z \alpha / 2) 2 p q}{d 2}$

$$
\mathrm{n}=\frac{n o}{1+n o / N}
$$

The formula for $n o$ olds also if $\mathrm{d}, \mathrm{p}$ and $\mathrm{q}$ are all expressed as percentages instead of proportions. Since the product $\mathrm{pq}$ increases as $\mathrm{p}$ moves toward $1 / 2$, or $50 \%$ a conservative estimate of $\mathrm{n}$ is obtained by choosing for $\mathrm{P}$ the value nearest to $1 / 2$ in the range in which $P$ is thought likely to lie in the total population proportion.

The factor taken into consideration for sample size determination were:

$>$ Level of confidence desired,

$>$ The maximum allowable error premitted in the estimate

$>$ The estimated population of success $\mathrm{P}$ 


$$
\text { For } n o=\frac{(Z \alpha / 2) 2 p q}{d 2}
$$

From the previous study, we assume $\mathrm{P}$ to be equal to 0.5 . Because given confidence level and marginal error the value of $\mathrm{P}$ being 0.5 will result in a larger sample size should be than any other value assumed by $\mathrm{P}$ so that the sample size should be atleast as large or larger than required for the given conditions.

Where, $\mathrm{p}=$ population proportion $50 \%$ since there is prior information suggesting a possible value for the sample prevalence .

$\mathrm{q}=1-\mathrm{P}$ (Population proportion 50\%)

$\mathrm{d}=$ degree of precision (margin of error ) $8 \%$

$\mathrm{N}=$ Total population of all students from the NSC

$\mathrm{n}=$ sample size of all students which were selected from each department of NSC

$\alpha=$ taken from the level of significance of $95 \%(\alpha=0.05)$

$n o=\frac{\left(\frac{Z \alpha}{2}\right) 2 p q}{d 2}=\underline{(1.96)^{2} \times 0.5 \times 0.5}=150$

$\mathrm{n}_{1}=\frac{n o}{1+n o / N}=\frac{(0.08)^{2}}{1+150 / 1087}=132$

$n o=\frac{\left(\frac{Z \alpha}{2}\right) 2 p q}{d 2}=\underline{(1.96)^{2} \times 0.5 \times 0.5}=150$

$(0.08)^{2}$

$\mathrm{n}_{2}=\frac{n o}{1+n o / N}=\frac{150}{1+150 / 75}=50$

Basically there are four major reasons for resorting to stratification,

$>$ The prencipal objective of stratification is to reduce sampling error.

$>$ In some cases, separate estimates are required at the statum level.

$>$ Stratified sampling is administratively convenient.

$>$ Sometimes, different parts of the population may call for different sampling procedures.

Therefore, the need of stratification that a population was divided into $\mathrm{n}$ mutually exclusive and exhaustive strata and SRS of $n_{h}$ element is taken separetly and independently with in each stratum.

To take sample from $1^{\text {st }}$ year upto $4^{\text {th }}$ year of all department students, proportional allocation was used. In proportion allocation small sample is taken from large population.

Table 1: Assumption of strata of students and teachers

\begin{tabular}{|c|l|l|}
\hline Strata number for students and teachers & Students department & Teachers department \\
\hline 1 & Statistics & Statistics \\
\hline 2 & Biology & Biology \\
\hline 3 & Physics & Physics \\
\hline 4 & Chemistry & Chemistry \\
\hline 5 & Geology & Geology \\
\hline 6 & Mathematics & Mathematics \\
\hline
\end{tabular}

Since for this study the appropriate sampling method was stratified sampling, the classification in each department was as follow:

Table 2: Number of students and teachers in each department

\begin{tabular}{|l|l|}
\hline \multicolumn{1}{|c|}{ Number of students in each department } & \multicolumn{1}{c|}{ Number of teachers in each department } \\
\hline $\mathrm{N}_{11}=$ Statistics & $\mathrm{N}_{21}=$ Statistics \\
\hline $\mathrm{N}_{12}=$ Biology & $\mathrm{N}_{22}=$ Biology \\
\hline $\mathrm{N}_{13}=$ Physics & $\mathrm{N}_{23}=$ Physics \\
\hline $\mathrm{N}_{14}=$ Chemistry & $\mathrm{N}_{24}=$ Chemistry \\
\hline $\mathrm{N}_{15}=$ Geology & $\mathrm{N}_{25}=$ Geology \\
\hline $\mathrm{N}_{16}=$ Mathematics & $\mathrm{N}_{26}=$ Mathematics \\
\hline $\mathrm{N}_{1}=$ Total number of students & $\mathbf{N}_{2}=$ Total number of teachers \\
\hline
\end{tabular}


Table 3: Sample number for each department students and teachers

\begin{tabular}{|l|l|}
\hline \multicolumn{1}{|c|}{ Sample number of students in each department } & \multicolumn{1}{c|}{ Sample number of teachers in each department } \\
\hline $\mathrm{n}_{11}=$ Statistics & $\mathrm{n}_{21}=$ Statistics \\
\hline $\mathrm{n}_{12}=$ Biology & $\mathrm{n}_{22}=$ Biology \\
\hline $\mathrm{n}_{13}=$ Physics & $\mathrm{n}_{23}=$ Physics \\
\hline $\mathrm{n}_{14}=$ Chemistry & $\mathrm{n}_{24}=$ Chemistry \\
\hline $\mathrm{n}_{15}=$ Geology & $\mathrm{n}_{25}=$ Geology \\
\hline $\mathrm{n}_{16}=$ Mathematics & $\mathrm{n}_{26}=$ Mathematics \\
\hline $\mathbf{n}_{1}=$ Total number of sampled students & $\mathbf{n}_{2}=$ Total number of sampled teachers \\
\hline
\end{tabular}

1. Total number of students $\left(\mathrm{N}_{1}\right)=\mathrm{N}_{11}+\mathrm{N}_{12}+\mathrm{N}_{13}+\mathrm{N}_{14}+\mathrm{N}_{15}+\mathrm{N}_{16}$

2. Total number of teachers $\left(\mathrm{N}_{2}\right)=\mathrm{N}_{21}+\mathrm{N}_{22}+\mathrm{N}_{23}+\mathrm{N}_{24}+\mathrm{N}_{25}+\mathrm{N}_{26}$

3. Total number of sampled students $\left(\mathrm{n}_{1}\right)=\mathrm{n}_{11}+\mathrm{n}_{12}+\mathrm{n}_{13}+\mathrm{n}_{14}+\mathrm{n}_{15}+\mathrm{n}_{16}$

4. Total number of sampled teachers $\left(\mathrm{n}_{2}\right)=\mathrm{n}_{21}+\mathrm{n}_{22}+\mathrm{n}_{23}+\mathrm{n}_{24}+\mathrm{n}_{25}+\mathrm{n}_{26}$

Then using proportional allocation the sample size was calculated as follows:

For students

Where $\mathbf{N}_{1}=1087 ;\left(\mathbf{N}_{11}=196, \quad \mathbf{N}_{12}=206, \quad \mathbf{N}_{13}=157, \quad \mathbf{N}_{14}=179, \quad \mathbf{N}_{15}=179, \quad \mathbf{N}_{16}=170\right)$

$$
\begin{array}{ll}
\checkmark & \mathrm{n}_{11}=196 * 132 / 1087=\mathbf{2 4} \\
\checkmark & \mathrm{n}_{12}=206 * 132 / 1087=2 \mathbf{5} \\
\checkmark & \mathrm{n}_{13}=157 * 132 / 1087=\mathbf{1 9} \\
\checkmark & \mathrm{n}_{14}=179 * 132 / 1087=\mathbf{2 2} \\
\checkmark & \mathrm{n}_{15}=179 * 132 / 1087=\mathbf{2 2} \\
\checkmark & \mathrm{n}_{16}=170 * 132 / 1087=\mathbf{2 1}
\end{array}
$$

\section{For teachers}

$$
\begin{aligned}
\text { Where } \mathbf{N}_{\mathbf{2}}=\mathbf{7 5} & \left(\mathbf{N}_{\mathbf{2 1}}=9, \quad \mathbf{N}_{\mathbf{2 2}}=13, \quad \mathbf{N}_{\mathbf{2 3}}=11, \quad \mathbf{N}_{\mathbf{2 4}}=13, \quad \mathbf{N}_{\mathbf{2 5}}=10, \quad \mathbf{N}_{\mathbf{2 6}}=19\right) \\
\checkmark & \mathrm{n}_{21}=9 * 50 / 75=6 \\
\checkmark & \mathrm{n}_{22}=13 * 50 / 75=9 \\
\checkmark & \mathrm{n}_{23}=11 * 50 / 75=7 \\
\checkmark & \mathrm{n}_{24}=13 * 50 / 75=9 \\
\checkmark & \mathrm{n}_{25}=10 * 50 / 75=7 \\
\checkmark & \mathrm{n}_{26}=19 * 50 / 75=12
\end{aligned}
$$

Table 4: Summary that shows sample size determination for students

\begin{tabular}{|c|c|c|c|}
\hline Stratum & Population size & Expected sample size & Actual sample taken \\
\hline 1 & 196 & 24 & 18 \\
\hline 2 & 206 & 25 & 18 \\
\hline 3 & 157 & 19 & 18 \\
\hline 4 & 179 & 22 & 26 \\
\hline 5 & 179 & 22 & 29 \\
\hline 6 & 170 & 21 & 20 \\
\hline Total & $\mathbf{1 0 8 7}$ & $\mathbf{1 3 3}$ & $\mathbf{1 2 9}$ \\
\hline
\end{tabular}

Table 5: Summary that shows sample size determination for teachers

\begin{tabular}{|c|c|c|c|}
\hline Stratum & Population size & $\begin{array}{c}\text { Expected sample size } \\
\mathbf{( 6 6 . 6 7 \% )}\end{array}$ & $\begin{array}{c}\text { Actual sample taken } \\
\text { (52\% of total) }\end{array}$ \\
\hline 1 & 9 & 6 & 3 \\
\hline 2 & 13 & 9 & 6 \\
\hline 3 & 11 & 7 & 6 \\
\hline 4 & 13 & 9 & 8 \\
\hline 5 & 10 & 7 & 8 \\
\hline 6 & 19 & 12 & $\mathbf{3 9}$ \\
\hline Total & $\mathbf{7 5}$ & $\mathbf{5 0}$ & 8 \\
\hline
\end{tabular}

Note: Even though the determined sample size of teachers' was 50 (66.67\%), we took only 39 numbers of teachers $(52 \%)$. We did this because we assumed that $52 \%$ is enough for sampling purpose.

\subsection{Methods of data analysis}

Data analysis was performed using computer software so called Statistical Packaging for Social Science (SPSS) model IBM SPSS Statistics 20.

\subsubsection{Variable identification}

Basically they are two types of variables. These are explanatory (independent) variable and response (dependent) 
variable. The explanatory (independents) variable is variable whose value is used to estimate dependent variable and also its variable which influences the values or is used for prediction. The response (dependent) variable explains that the variable whose values used to estimate by the independent variable. Therefore, the variables that were used in the study area as follow:

Dependent (response) variable:-

$>1$ to 5 group as Change Army activities

Independent (explanatory) variable:-

Department

$>$ Sex

$>$ Semester

$>$ Class year

$>$ Attitude

$>$ Activity in 1 to 5 groups

$>1$ to 5 groups starting time

$>1$ to 5 meeting time

$>$ Type of report

$>$ Frequency of applying 1 to 5 change army

$>$ Descrption of 1 to 5 change army discussion

\section{Results and discussion}

\subsection{Descriptive statistics for students}

\subsubsection{General information}

This action research was conducted in NSC for all bach students from first upto fourth year students. Within this spectrum, 30.2\% (from first year), 29.5\% (from second year), 31.8\% (from third year), and 6.9\% (from fourth year) involved in this research. As a clarification, out of 129 sampled respondents $68.2 \%$ male and $31.0 \%$ female students were participated. To encompass the three level participants of 1 to 5 groups, that is, leaders $(47.3 \%)$, members $(38.8 \%)$ and secretary $(14.0 \%)$ were involved in this research.

\subsubsection{Activities of students in 1 to 5 groups}

To implement 1 to 5 group activities through Change Army participants, the participants should have basic information about the purpose and importancy of this group formation. Based on this concept within our faculty $76.0 \%$ students have basic information. However, small number of students about $23.3 \%$ has no clear information. Even though majority of the students have basic information, yet remain much efforts to bring those not informed students into the situation. In comparison among the department students, however, biology (83.3\%), chemistry $(96.2 \%)$, mathematics $(90.0 \%)$, geology $(51.7 \%)$, physics $(77.8 \%)$ and statistics $(61.1 \%)$ were well informed about the purpose and importancy of Change Army.

As per the respondents within the faculty, creation of awareness has been obtained from media $(11.6 \%)$, orientation (40.3\%), and training (22.5\%). This indicated larger percent in creation of awareness for the students has been obtained through orientation. Accordingly, creation of awareness about the purpose and importancy of Change Army within the faculty has been given by the department heads (43.4\%) though it was below half percent. To speculate how much percent each department head were giving orientation to their students, this research investigated about it and obtained the following results: biology $(66.7 \%)$, chemistry $(57.7 \%)$, mathematics $(15.0 \%)$, geology (41.4\%), physics (66.7\%) and statistics (11.1\%). This revealed there were three departments which obtained above half percent (biology, chemistry and physics) and there were also other three departments (mathematics, geology and statistics) which obtained below half percent. As a suggestion those who obtained below half percent should give much emphasize about the clarification of Change Army group formation within their department.

The department heads were not simply delivering the information but also they created the students to have 1 to 5 grouping. All departments have made such grouping above $90 \%$. Generally, in the faculty level $92.2 \%$ the students were grouped. However, this great percentage in all departments it can be appreciated though it contradicts for those three departments (mathematics, geology and statistics) which have made creation of awareness about the purpose of Change Army below half percent. While formation of groups was in greater percentage which was around $90.0 \%$, creation of awareness about the purpose could not be much lesser than half present. If that was really happening, the three departments might be simply informing the students only to have groups. Nevertheless, care should be taken when each department implement students group formation. They should clarify about the purpose and they have to make the students happy on their group formation.

Even though creation awareness and forming of 1 to 5 grouping is very pertinent, regular meeting is necessary to follow up the situation and to improve group activities. Based on this assumption within the faculty $71.3 \%$ students have regular meeting. However, majority percent was done by biology $(88.9 \%)$, statistics $(88.9 \%)$, physics 
$(83.3 \%)$ and mathematics students $(80.0 \%)$. In contrast, lesser percentage in regular meeting activity was practiced by chemistry $(65.4 \%)$ and geology students $(41.4 \%)$. In a faculty level $25.6 \%$ and from the department of physics students $61.1 \%$ replayed this regular meeting has been practiced once in a week. The remaining department students replayed below $35 \%$.

Unless the group meeting discussion is recorded and reported to the concerned body, solution may not be given. Of course, some problems might be resolved through discussion. However, to tackle serious problems and to have better plan for the future work, recording and reporting of the discussion outcome to the concerned body is very pivotal. In our faculty students $69.0 \%$ were practicing this activity. In comparison among the department students, however, mathematics $(95.0 \%)$, statistics $(83.3 \%)$, and chemistry $(80.8 \%)$ have been practicing. Other department students such as biology (61.1\%) and physics students $(61.1 \%)$ are above average. However, the geology students are in $41.4 \%$ which is below an average. This recording and reporting activity among the students in the faculty have been done by letter $(15.5 \%)$ and minutes $(11.6 \%)$. Even though majority of the students have recorded and reported to the concerned body, their satisfaction in obtaining of the right answer was somehow good because $65.6 \%$ of the students in the faculty have obtained right answer response for their problems.

Clear and tangible discussion to the concerned problem is necessary because to be specific and reasonable. If the discussion is out of the agenda, the meeting will be wasting of time rather than solving of the problems. In a faculty level $33.3 \%$ the students have discussed and resolved their problems. However, during their discussion $17.8 \%$ of the students said their meeting was focus much on blaming each other than giving ideas how to eradicate the obstacles about teaching activities.

\subsubsection{Role of teachers' on students' 1 to 5 group activity}

To involve the students in their group work activities, the teachers' assessment method will contribute a great role. In the faculty level $90.7 \%$ of students replayed their teachers were giving group assignments as per students' 1 to 5 grouping. However, about $9.3 \%$ of students responded that their teachers were not giving group assignments as per their grouping. To speculate how many of the teachers were using students 1 to 5 grouping, the students were asked to respond. Accordingly, about 43.4\% said all teachers were using their 1 to 5 grouping. In contrast, a comparable number about $39.5 \%$ responded that few teachers and about $16.3 \%$ very few teachers were using (totally 55.8\%). In a faculty level, this total percent indicated majority of teachers were not using students 1 to 5 grouping. This is may be the teachers may not have sufficient awareness about the purpose of students' 1 to 5 grouping or may not believe on it.

It is not only giving group work activity for the students that boosts their cooperative learning but also the frequency will matter. Majority of the students $27.9 \%$ said two times in a course their teachers were giving them group works as per their 1 to 5 grouping. Even though 55.0\% of the respondent believed their 1 to 5 grouping was helping them to enhance their cooperative learning, $18.6 \%$ did not believe about it. Based on this assumption $45.0 \%$ have positive attitude while $16.3 \%$ have strong negative attitude. Therefore, this indicated that not all students were happy on their 1 to 5 grouping.

Finally, the students have evaluated their 1 to 5 group implementation within their department. Based on this evaluation, in a faculty level $34.9 \%$ of the students gave "Good" mark and $22.5 \%$ "poor". In comparison among the departments, however, biology (55.6\% Good and 5.6\% Poor), chemistry (30.8\% Good and 19.2\% Poor), mathematics (30.0\% Good and 25.0\% Poor), geology (27.6\% Good and 31.0\% Poor), physics (27.8\% Good and $5.6 \%$ Poor) and statistics (44.4\% Poor and $44.4 \%$ Good) have got students' evaluation. From this result, those departments which obtained smaller percent for the good mark than poor, should give much emphasize about their assignment to bring the students in a common understanding of the purpose and importancy of 1 to 5 grouping.

\subsubsection{Students' attitude and perception towards to group activity}

To measure the level of students' attitude and perception towards to group activity, the following questions were asked to the faculty students whether group activity encourage the development of critical thinking skill or not. Based on this, $38.0 \%$ the students agreed and $30.2 \%$ strongly agreed with the question. But, about $10.1 \%$ students disagreed. Nowaday, it has been believed that cooperative learning will promote students learning achievement. About this believe the students were asked whether they agree or disagree. The research revealed $34.1 \%$ of the students agreed and $32.6 \%$ strongly agreed. However, about $18.6 \%$ of sampled students disagreed.

Currently, rather than lecturing method to apply in teaching activity student centered approach is believed that students can learn by their own by involving in every activity. The faculty students (34.1\%) have agreed with this assumption while $17.1 \%$ disagree about this concept. Moreover, social skill and interaction can be enhanced during in students' collaboration work. With this believe out of 129 sampled students $36.4 \%$ agreed and $16.3 \%$ disagreed. Furthermore, collaboration work will enhance the teaching, learning and assessment options. The students were again asked about this benefit. Only about $39.5 \%$ of the faculty students have agreed and $23.3 \%$ disagreed.

\subsubsection{Identified problems for students' cooperative learning}

The following tables illustrate the expected problems that hinder cooperative learning among the students during their 1 to 5 group activities and which bring low achievement in their day-to-day learning activity. To differentiate 
which of the following factors were dominantly affecting the students, the following questionnaires were presented for the students and the results were obtained as shown below.

\begin{tabular}{|l|l|l|l|l|l|}
\hline Problem & Agree & Disagree & $\begin{array}{l}\text { Strongly } \\
\text { Agree }\end{array}$ & $\begin{array}{l}\text { Strongly } \\
\text { Disagree }\end{array}$ & Undecided \\
\hline $\begin{array}{l}\text { Lack of follow up and encourage } \\
\text { response from the concerned body }\end{array}$ & $27.9 \%$ & $22.5 \%$ & $34.9 \%$ & $9.3 \%$ & $1.6 \%$ \\
\hline $\begin{array}{l}\text { Behavior of your friends (peer } \\
\text { pressure) }\end{array}$ & $32.6 \%$ & $16.3 \%$ & $30.2 \%$ & $8.5 \%$ & $10.9 \%$ \\
\hline $\begin{array}{l}\text { Your leader is not giving opportunity } \\
\text { to participate }\end{array}$ & $23.3 \%$ & $34.1 \%$ & $15.5 \%$ & $15.5 \%$ & $9.3 \%$ \\
\hline Your shyness to participate & $38.0 \%$ & $25.6 \%$ & $11.6 \%$ & $13.2 \%$ & $9.3 \%$ \\
\hline $\begin{array}{l}\text { Your groups are not willing to } \\
\text { participate }\end{array}$ & $28.7 \%$ & $23.3 \%$ & $21.7 \%$ & $16.3 \%$ & $7.8 \%$ \\
\hline The grouping method is not inclusive & $26.4 \%$ & $30.2 \%$ & $20.9 \%$ & $13.2 \%$ & $7.0 \%$ \\
\hline $\begin{array}{l}\text { Because of one member dominate the } \\
\text { participation }\end{array}$ & $24.8 \%$ & $38.8 \%$ & $18.6 \%$ & $8.5 \%$ & $5.4 \%$ \\
\hline $\begin{array}{l}\text { Your friends discourage you during } \\
\text { participation }\end{array}$ & $17.8 \%$ & $33.3 \%$ & $21.7 \%$ & $11.6 \%$ & $14.7 \%$ \\
\hline $\begin{array}{l}\text { Because of lack of educational } \\
\text { material(s) and other resources }\end{array}$ & $31.8 \%$ & $24.8 \%$ & $27.1 \%$ & $9.3 \%$ & $6.2 \%$ \\
\hline Problem of language & $27.1 \%$ & $21.7 \%$ & $26.4 \%$ & $18.6 \%$ & $5.4 \%$ \\
\hline $\begin{array}{l}\text { Being dependent on few respondents } \\
\text { during discussion }\end{array}$ & $27.9 \%$ & $27.9 \%$ & $22.5 \%$ & $12.4 \%$ & $7.8 \%$ \\
\hline
\end{tabular}

\subsection{Descriptive statistics for teachers}

\subsubsection{General information}

In this action research six department teachers of NSC were participated. In a faculty level $94.9 \%$ male and $5.1 \%$ of female instructors were participated. Based on employee date, since there are different instructors who have been serving this university, this research tried to cover all employee dates starting from 2003 E.C upto the time of this research conducted which is 2009 E.C. By differentiating their service years, the following results were obtained. The instructors who have less than one year (30.8\%), 1 upto 2 years $(23.1 \%), 3$ upto 4 years $(25.6 \%)$ and 5 upto 6 years of experience $(20.5 \%)$ were involved in this research. These instructors have a different educational background because there are B.Sc. $(25.6 \%)$, M.Sc. $(69.2 \%)$ and $\mathrm{PhD}(0 \%)$ participants. This level tells us majority of the instructors who have conducted on this research was M.Sc. holder. To encompass all kinds of the three levels 1 to 5 group participants, the research also included members (53.8\%), secretary (17.9\%) and leaders $(25.6 \%)$

\subsubsection{Activity of teacher in 1 to 5 groups}

It is a common fact that teachers are well educated and need reasonable information for particular truth. Creation of clear awareness about the purpose and importancy of Change Army through formation of 1 to 5 groups is very pertinent to enhance their level of cooperative work within the department. Based on this scenario, within our faculty $74.4 \%$ of the participant instructors have well informed. However, small number of instructors about $23.1 \%$ has not been informed. Even though majority of the instructors have basic information, yet remain much efforts to bring those not informed instructors into the situation. Similarly, in comparison among the departments instructors biology $(50 \%)$, chemistry $(62.5 \%)$, mathematics $(100 \%)$, geology $(62.5 \%)$, physics $(83.3 \%)$ and statistics $(100 \%)$ were well informed about the purpose and importancy of Change Army.

As per the respondents within the faculty, creation of awareness about the purpose has been obtained from media $(2.6 \%)$, orientation $(38.5 \%)$, and training $(20.5 \%)$. This revealed, larger percent in creation of awareness was obtained through orientation. This orientation about $30.8 \%$ has been delivered by the department heads. To point out how much percent they were giving orientation to their instructors, this research investigated about it and obtained the following results: biology $(83.3 \%)$, chemistry $(0 \%)$, mathematics $(0 \%)$, geology $(50 \%)$, physics $(50 \%)$ and statistics $(0 \%)$. Those departments who obtained above $50 \%$ they are in a good track but those obtained lower than $50 \%$ have to boost their activity by informing their instructors about the purpose of Change Army activity in line with the goal of our university and the purpose of teaching activity. Especially, chemistry, statistics and mathematics department instructors responded that they were not obtaining such clarification. This is may be the trend in which the current department heads may think that previously the instructors obtained sufficient orientation by the concerned body.

Beside this drawback, the department heads were not simply delivering the information but also they created the teachers to have 1 to 5 grouping. According to this study, $100 \%$ of the respondents reported that they have 
been grouped in to 1 to 5 groups in each department. However, this result contradicted with the above results especially for chemistry, statistics and mathematics departments in which their instructors responded that no orientation was given about the purpose of 1 to 5 grouping. However, how it is possible creation of 1 to 5 groups without telling of the importancy and purpose of 1 to 5 groups? In this regards the instructors may not understand the question or they might be unintentionally jumped that question.

Formation of Change Army groups in NSC started in 2003 E.C and it continues upto now, 2009 E.C. This is because, based on the following data result, in every year there is group formation within the departments. For instance, in a faculty level the respondents said in 2003 E.C (7.7\%), 2004 E.C (5.1\%), 2005 E.C (2.6\%), 2006 E.C $(23.1 \%), 2007$ E.C (35.9\%), 2008 E.C (17.9\%) and in 2009 E.C (7.7\%) have made Change Army group. This revealed there were dramatically decreasing in group formation from the beginning upto 2005 E.C. Again after 2005 E.C year the data indicated there was a slight increment in 2006 E.C and 2007 E.C. However, starting from 2007 E.C upto now which is the time of this research conducted (2009 E.C) Change Army group formation within our faculty become lowdown and loosely practiced.

Even though creation awareness and forming of 1 to 5 grouping is very pertinent, regular meeting is necessary to follow up the situation and to improve group activities. Based on this assumption within the faculty $87.2 \%$ teachers have regular meeting. However, majority percent was done by chemistry $(87.5 \%)$, geology $(100 \%)$, mathematics $(100 \%)$, and physics $(83.3 \%)$ teachers. In contrast, lesser percentage to the above departments but above half percent in regular meeting activity has been practiced by biology $(66.7 \%)$ and statistics teachers $(66.7 \%)$ Again in a faculty level $68.4 \%$ and from the different departments, chemistry teachers $(71.4 \%)$, physics teachers $100 \%$ and geology $100 \%$ replayed this regular meeting has been practicing once in a week. However, the remaining department teachers replayed below $50 \%$.

Unless the group meeting discussion is recorded and reported to the concerned body, solution may not be given. Of course, some problems may be resolved during discussion time. However, to tackle serious problems and to have better plan for the future work, recording and reporting of the discussion outcome to the concerned body is very pertinent. In our faculty, $92.3 \%$ teachers have recorded and reported to their department. In comparison among the department teachers, however, mathematics (100\%), statistics (100\%), geology (100\%), chemistry $(87.5 \%)$, biology $(83.3 \%)$ and physics teachers $(83.3 \%)$ have been doing this activity. Since the recording method was important, in the faculty level teachers have been reporting by letter (38.5\%) and minutes $(23.1 \%)$. In contrast to this result, $7.7 \%$ teachers said no report was done and $7.7 \%$ said orally they were reporting the activity. This oral reporting is not a good way of communication especially those who have future plan. Even though majority of the teachers have recorded and reported to the concerned body, their satisfaction in obtaining of the right answer of their question was somehow good because $56.4 \%$ of the teachers in the faculty responded that they have obtained right answer for their problems. However, undeniable larger number of teachers about $38.5 \%$ said that they did not obtain response to their questions. This situation may discourage the participants in cooperative working and may lead in aggravated problems.

Clear and tangible discussion to the concerned problem is also necessary because to be specific and reasonable. If the discussion is out of the agenda the meeting will be wasting of time rather than solving of the problems. Regarding to this assumption, in a faculty level $28.2 \%$ of teachers have discussed and resolved their problems. However, during their discussion $15.4 \%$ of the teachers said their meeting focus much on blaming each other than giving ideas how to eradicate the obstacles about teaching activities. Even 17.9\% were dissatisfied on their meeting because they believed that their discussion had no tangible and visible outcomes. Other teachers about $12.8 \%$ believed the discussion was about political affairs rather than academic agenda. Finally, 5.1\% said their discussion has ethnic clustering during discussion time. This research finding indicated there was no clear understanding about the purpose and importancy of 1 to 5 group formation and what their discussion should focus during the meeting time. Therefore, such ambiguity must be clearly defined and restated to have a commonsense.

\subsubsection{Role of teachers on students' 1 to 5 group activity}

It is a common fact that to involve the students in their group work activities, the teachers' assessment method will contribute a great role in their learning achievement. In the faculty level $89.7 \%$ of teachers were using students' 1 to 5 group for the purpose of group assignments. But not all teachers were using students' 1 to 5 group. About $10.3 \%$ of teachers were not using students' 1 to 5 group for any cooperative learning. This is may be the students were not willing in their cooperative working. This is because majority of teachers about $51.4 \%$ said only few students were willing for group work activities. In addition, $2.7 \%$ of teachers said very few students were willing. In contrast to this results, $21.6 \%$ of teachers agreed that all students were willing for the group work. However, $24.3 \%$ of teachers said half of the students were willing.

It is not only giving group work activity for the students that boosts their cooperative learning but also the frequency will matter to follow-up their performance level. In our faculty majority of the teachers about $28.9 \%$ responded that two times in a course they were giving group works as per students' 1 to 5 grouping. However, lesser percent to this responded that about $5.3 \%$ were using once in a course, $21.1 \%$ three times in a course, $18.4 \%$ four times in a course, $7.9 \%$ five times in a course, and $18.4 \%$ more than six times in a course. 
Even though $59.0 \%$ of the respondent believed their 1 to 5 grouping was helping them to enhance their cooperative learning, $25.6 \%$ did not believe about it. Based on this assumption, $51.3 \%$ have positive and $17.9 \%$ strong positive attitude (totally $69.2 \%$ ) while $12.8 \%$ have strong negative and $10.3 \%$ negative attitude (totally $23.1 \%)$.

Finally, the teachers have evaluated their 1 to 5 group implementation within their department. Based on their evaluation, in a faculty level $43.6 \%$ of the teachers gave "Good" mark and $25.6 \%$ of the respondent gave "poor". In comparison among the departments, however, biology ( $100 \%$ Good $)$, chemistry $(25.0 \%$ Good and $50.0 \%$ poor $)$, mathematics $(25.0 \%$ Good and $37.5 \%$ poor), geology (37.5\% Good and $25.0 \%$ poor), physics $(33.3 \%$ Good, satisfactory $16.7 \%$ and $0 \%$ poor) and statistics (66.7\% Good and $33.3 \%$ poor) have got teachers' evaluation. In all department the "Good" mark is in higher percent than "poor" except chemistry and mathematics in which they obtained lesser "Good" mark than "poor". This tells us the two departments must improve their activities.

\subsubsection{Teachers' attitude and perception towards to group activity}

To measure the level of teachers' attitude and perception towards to group activity, the following questions were asked to all department teachers whether group activity encourage the development of critical thinking skill or not. Based on this question, $28.2 \%$ of the teachers agree and $20.5 \%$ strongly agree with the assumption. But, $30.8 \%$ disagree and $10.3 \%$ strongly disagree. It has been believed that cooperative learning will promote teachers cooperative learning and research achievement. Accordingly, this research revealed $28.2 \%$ of the teachers agreed and $25.6 \%$ strongly agreed. However, about $20.5 \%$ of sampled teachers disagree and $15.4 \%$ strongly disagree.

Currently, rather than lecturing method to apply in teaching activity, student centered approach is believed that students can learn by their own through involving in every activity. To look for this assumption in every sampled teacher whether they believe and are willing to apply, this question was asked to them. In a faculty lave $25.6 \%$ have agreed and $35.9 \%$ strongly agree (totally $61.5 \%$ ) with this assumption while a lesser percent $20.5 \%$ disagree and $7.7 \%$ strongly disagree (totally $28.2 \%$ ) about this concept. This indicates undeniable numbers of teachers were not practicing student-center teaching-learning process.

Working in collaboration with others is one way of social communication. Doing such relationship has been believed in the way that the teachers' social skill and interaction can be enhanced during their collaboration work either in academic performance or community service. With no social communication the challenging problems that are rising up and facing us in a day to day activity cannot be solved. With this believe and assumption in a faculty level $28.2 \%$ agreed and $25.6 \%$ strongly agree (totally $53.8 \%$ ) while a lesser percent $17.9 \%$ disagreed and $5.1 \%$ strongly disagree (totally 23.0 ). In addition to this, collaboration work will also enhance the teaching-learning and assessment method options. Accordingly, $43.6 \%$ of sampled teachers have agreed and $23.1 \%$ strongly agree (totally $66.7 \%$ ), and $12.6 \%$ disagreed and $7.7 \%$ strongly disagree (totally $20.3 \%$ ).

\subsubsection{Identified problems for teachers' cooperative learning}

Nowaday, 1 to 5 group working has not yet brings the desired changes as described above its purpose and importancy. The following tables illustrates the expected problems that hinder cooperative learning among the teachers during their 1 to 5 group activities and which bring low achievement in their day-to-day learning activity. To differentiate which of the following factors were dominantly affecting the teachers, the following questionnaires were presented for them and the results were obtained as shown below.

\section{Teachers' and students' plan and feedback on Change Army activity}

\subsection{Students' response}

6.1.1. Students' response on the progress change of their 1 to 5 grouping

- It was helping us to communicate each other and solve our problems

- It was helping us to teach one each other

- It was helping us to share our work load

- It increased our assessment method

- It was helping us to obtain higher mark

- It was helping us to have a better confidence in sharing of our idea

- To some extent it bring student-center learning process

- It was helping us to be active rather than passive learner

- It was helping us to have good communication with the department heads

6.1.2. Students' comment on leaders, teachers and students what they have to do for the success and achievement of 1 to 5 grouping

- They have to work as together in a cooperative learning manner

- $\quad$ The teachers must respect their students and vis versa.

- Leaders must give chance for the participants

- Teachers must encourage their students especially during group work

- Students must respect their duty and obligation 
- They should have planned time for collaboration work

- Teachers must increase usage of students 1 to 5 group to increase their activity

- Group leaders must encourage their participants during collaboration work

- $\quad$ Each group members should understand the importancy of 1 to 5 grouping

- Department heads or teachers should help the students by giving educational materials

- Group leaders should monitor teachers' activity whether they are willing to show students' test and grade

6.1.3. Students' plan how to use their 1 to 5 grouping for the future work

- By respect our teachers and colleague we planned to work more on cooperative learning

- We planned to have good commitment for our group works

- Because we believed 1 to 5 grouping is helping us, we will improve our positive attitude about it

- $\quad$ To increase our grade by doing more through 1 to 5 group work

- To improve our attitude towards to our department by considering how much it is helpful

- To increase our participation during collaboration work

- $\quad$ To read and work more as together using 1 to 5 group activity

- To boost our meeting time especially once in a week

\subsection{Teachers' response}

\subsubsection{Teachers' response on the progress change of their 1 to 5 grouping}

- Very good ideas were raised during our meeting time and it was helping us in learning activity

- We obtained peer group discussion in exchanging of some knowledge

- No change has been obtained because it was simply wasting of time

- We raised important ideas and issues. However, for our problems no response was given from the concerned body

- $\quad$ Easy problems were solved during our meeting time

- It encourages the critical thinking of teachers and students. This is because through time to time our communication was enhanced in a good manner

- We were sharing some educational materials during our 1 to 5 group discussion

- We had strong collaboration work

- It was helping us to identify our students participation level

- It was helping us to manage our time and students

- It was helping us to increase our social interaction

- Our students' participation was improved when we use their 1 to 5 group

- It increased students' assessment method

6.2.2. Teachers' comment on leaders, teachers and students what they have to do for the success and achievement of 1 to 5 grouping

- All staffs have to develop communication skills

- Every member of 1 to 5 groups should respect and follow our university rules and regulation about Change Army activity

- All members should increase their willingness in doing of cooperative work

- The members should improve their activity for the success of Change Army

- They should have clear objective about the purpose of Change Army

- Group leaders should coordinate the activity by taking of their responsibility

- Teachers should use students' 1 to 5 grouping for better learning process

- Students should not be dependent on others work during collaboration work

- Teachers must motivate, advise and guide their students in a progress way

- Students should participate for their group work

- Generally there must be strong follow-up by responding the presented problems

- It would be better if 1 to 5 group activity implement by plan

6.2.3. Teachers' plan how to use their 1 to 5 grouping for the future work

- To actively participate during our proceeding time

- To give motivational training for the students towards to 1 to 5 group activity

- To change students' poor perception about 1 to 5 Change Army activities

- To boost students' assessment method using their 1 to 5 Change Army groups

- To prepare different activity which can be done by students' 1 to 5 Change Army 


\section{Acknowledgement}

First and for most we would like to thank Blue Hora University, College of Natural and Computational Science who gave us this opportunity to assess the current situation of Change Army activity in its implementation through all six departments. We would like also to tank in advance for those teachers and students who kindly participated in this research work.

\section{References and bibliography}

Adams, D. M., and Hamm, M. (1994). New designs for teaching and learning. San Francisco, CA: Jossey-Bass Inc.

ASHE-ERIC Higher Education Reports. Washington, DC: The George Washington University, School of Education and Human Development.

Astin, A. W. (1993). Assessment for excellence: The philosophy and practice of assessment and evaluation in higher education. New York, NY: Oryx Press.

Cooper, J. S., Prescott, L., Cook, L., Smith, R. M., and Cuseo, J. (1990). Cooperative learning and college instruction: Effective use of student learning teams. Long Beach, CA: California State University Academic Publications Program.

Cooper, J., Robinson, P., and McKinney, M. (1993). Cooperative learning in the classroom. San Francisco: JosseyBass.

Johnson, D. W., Johnson, R. T., and Smith, K. A. (1991). Cooperative learning: Increasing college faculty instructional productivity. ASHE-ERIC Higher Education Report No. 4, George Washington University.

Johnson, D. W., Johnson, R.T. and Smith, K. (2007). The state of cooperative learning in postsecondary and professional settings. Educational Psychology Review, 19, 15-29.

Menges, R. J. and Weimer, M. (1996). Teaching on solid ground: Using scholarship to improve practice. San Francisco, CA: Jossey-Bass Inc.

Slavin, R. E. (1989). Research on cooperative learning: An international perspective. Scandinavian Journal of Educational Research, 33, 231-243.

Slavin, R. E. (1996). Education for all: Contexts of learning. Lisse, The Netherlands: Swets \& Zeitlinger. 